\title{
Editorial: Theoretical Museology in Tribal Contexts
}

\section{Robert Denning}

\section{OpenEdition}

\section{Journals}

\section{Electronic version}

URL: https://journals.openedition.org/iss/3005

DOI: 10.4000/iss.3005

ISSN: 2306-4161

\section{Publisher}

ICOM - International Council of Museums

\section{Printed version}

Date of publication: 18 December 2021

Number of pages: $33-38$

ISBN: 978-92-9012-446-7

ISSN: 2309-1290

\section{Electronic reference}

Robert Denning, "Editorial: Theoretical Museology in Tribal Contexts", ICOFOM Study Series [Online], 49-1 | 2021, Online since 18 December 2021, connection on 08 January 2022. URL: http:// journals.openedition.org/iss/3005 ; DOl: https://doi.org/10.4000/iss.3005 


\title{
Editorial: \\ Theoretical \\ Museology in \\ Tribal Contexts
}

\author{
Robert Denning \\ Southern New Hampshire University - \\ Manchester, New Hampshire, USA
}

\section{Introduction}

On two days in August of 2020, Yun Shun Susie Chung and I hosted "Theoretical Museology in U.S. and Tribal Contexts," a symposium held in collaboration with the International Committee for Museology (ICOFOM), the International Council of Museums (ICOM US), the Association of African American Museums (AAAM), and Southern New Hampshire University (SNHU). We organized panels of presentation along four themes: defining "museology," teaching theoretical museology, the ethics of museology, and applying theoretical museology to real-world museums and other institutions. This volume includes many of the presentations from that symposium and a couple of supplemental papers that expand on and provide context for those four themes.

This symposium was only my second foray into the world of museology. Two years earlier, Susie and I (along with my colleague James Fennessy) hosted a symposium that contributed to ICOFOM's worldwide effort to redefine the word "museum" for the $21^{\text {st }}$ century. As I mentioned in that meeting, and in the publication that came out of it, I was new to the museology field at that point; I had never taken any coursework on, or worked in, museums, and the preparation for that symposium was a very fast but immersive introduction to the field for me. Three major themes stood out to me. First, museology is a relatively young field, with serious study of the theories and practicality 
of museums becoming a concern to scholars only in recent decades. Second, museums have been undergoing a dramatic transformation in those same recent decades, to become more experimental, more community-oriented, more inclusive, more interested in narratives and themes, and more engaging for visitors. Third, museums are becoming more activist in their programming and more forcefully advocating for the interests of their local communities (Denning, 2019).

While that crash course in Museology 101 did not make me an expert in the field, it did prompt me to pay more attention to the theories and practices of museums afterward. Every time I visit a museum now, I find myself paying more attention to the lists of upcoming events, the amount of space dedicated to community gatherings, and even the number of benches scattered throughout where visitors can rest and contemplate. My interest in benches came out of a conversation with Ann Davis, who brought it up as a brief example, but it stuck with me; I always look for the number and placement of benches now (Davis, Denning, and Chung, 2018). I live in a small suburb of Columbus, Ohio, and our town museum has not embraced these trends, or benches, as much as I expect them to in the future. Thankfully, there are a lot of benches at places like the National Museum of African History and Culture in Washington, DC, as I observed in April 2019. But beyond benches, I also find myself paying more attention to museums' wayfinding systems, the placement and content of plaques for exhibits, and how well the museum tells the story of the community.

It was, and is, odd to talk about museums during the COVID-19 pandemic. As of this writing, in September of 2021, many institutions are still closed to the public or closed completely. I hope that people around the world used the "break," if you want to call it that, to think about how various industries and organizations can work differently in the future, since they were freed from the hustle and bustle of everyday operations. I look forward to seeing how our world will change, hopefully for the better, after the pandemic has passed and we can all get back to normal operations (whatever "normal" will mean at that time). This is a chance for decision makers, curators, and other museum personnel to put into action the ideas that have been bouncing around in the heads of theoretical museologists for years. Let's hear about those ideas from the experts.

\section{Decolonizing the Museum}

Perhaps the most important trend in museology today is the ongoing attempt to decolonize museums, which in the past have been used to educate mostly white Western audiences about other cultures and peoples in a comfortable to white Westerners - context. Museums existed because colonization efforts had allowed the plunder of natural and man-made artifacts. That is changing. In his keynote address at the 2020 symposium, Bruno Brulon Soares argued that museums and museologists should not be afraid to be fierce advocates 
for their communities. Museums and museum professionals should encourage discussions, debates, and dialogue in their communities and across borders and boundaries. They must not shy away from politics or hard questions. They must confront the past, present, and future of their communities. In many places in the United States and around the world, museums are centers of community because they are places where people come together to talk about the past and chart the future (Brulon Soares, 2020).

The theories and principles behind modern museology are undergoing fundamental transformations because of challenges like Bruno's, as Yun Shun Susie Chung makes clear in her contribution to this volume. Museum professionals are trying to develop new definitions for the concepts of "museum" and "museology." As ICOM, ICOFOM, and other organizations attempt to find a new definition of "museum" for the $21^{\text {st }}$ century, Chung argues, the museum community also needs to find an accurate definition of "museology" that incorporates the decolonization effort. With the redefinition and reconceptualization of museology, museologists need to figure out how to teach those concepts, how to incorporate new systems of ethics, and how to apply those new definitions and priorities in museums. Chung proposes that her concept of "naculture" be a starting point in launching these discussions. Naculture emphasizes and incorporates indigenous understandings of culture and nature, which is essential to an accurate representation of indigenous peoples. All of this is to say that it is the ethical responsibility of researchers and museum professionals to collaborate with their subjects in developing exhibits, museums, and communities.

Chung is not alone in this quest. In this volume, Jessie Ryker-Crawford calls for new theories and practices that will replace the old colonial processes that held sway for so long in museums. These new theories and practices emphasize collaboration with indigenous communities. Ryker-Crawford explains how the Institute of American Indian Arts Museum Studies program put these new theories into practice by facilitating a gathering of tribal elders and youths to develop ideas for an exhibit. The resulting conversations uncovered and corrected numerous errors and sparked a discussion about the intersections of a changing natural environment, ecology, and government policies.

Alyce Sadongei argues that existing professional museological ethical standards are not rigorous enough to successfully and completely decolonize museums. Those institutions that contain indigenous artifacts or claim to represent indigenous peoples need to adopt the ethics of those indigenous communities. As Sadongei explains it, these indigenous ethics consist of cultural values, attitudes, and beliefs that include family, religion, language, community, and the natural and spiritual worlds. Successful efforts to bring indigenous ethics into the museum include the Makah Cultural and Research Center in Neah Bay, Washington, which provides genealogical services to help rebuild families and teaches tribal members how to balance traditional culture with the modern world; the Ak-Chin Indian Community in Arizona, which treats artifacts as 
the intersection of past and present; and the Huhugam Heritage Center, which teaches language as a way of expressing knowledge and transmitting culture.

Minnie Coonishish provides a success story in the effort to decolonize museums in the Eeyou Istchee territory in Quebec. The Aanischaaukamikw Cree Cultural Institute's research philosophy emphasizes inclusion and collaboration between indigenous tribes and outsiders. The Institute has built relationships with local schools, hosted workshops and training sessions, and sponsors the indigenous art community through artists-in-residence programs. Using "nothing about us, without us" as its guiding philosophy, the Institute focuses on the needs of the community when developing exhibitions, incorporates the Cree worldview into its library by using an indigenous-specific catalog classification system, and shares its work inside and outside of the Eeyou Istchee area.

Victoria Miller presents another successful application of the ideals of diversity and inclusivity in her essay on the activities of the Steelworks Center of the West in Pueblo, Colorado, which houses the abandoned records of the Colorado Fuel \& Iron Company. As Miller describes it, museums can be successful alternatives to traditional methods of study and can foster non-conformist thinking because each visitor experiences the collections and activities differently. Although the Center focuses on one company in one industry, great care is taken to develop exhibits and programming for all of the ethnicities and cultures that call the area home, including festivals with folklore, dancing, and food.

While our symposium focused on tribal contexts in North America, Obay Al Bitar provides a valuable service by drawing our attention to the plunder and colonization of indigenous peoples in the Middle East. European scholars in the $19^{\text {th }}$ and $20^{\text {th }}$ centuries interpreted and represented Islamic artwork in ways that enforced racial stereotypes and encouraged racial separation. In recent decades, institutions like the British Museum have begun to instead focus on the interactions between the East and the West and explain how Islamic art was an important influence on the development of the arts in Europe. In this way, the Islamic world and representations of it have begun the decolonization process.

Decolonization has been guiding museum policies and practices in other regions as well. Leandro Guedes provides a fascinating history of museological thought in Brazil and uses the Indian Museum of Rio de Janeiro as a case study of how decolonization can occur. Beginning with an exhibition on the Wajãp people in 2002, curators at the Indian Museum sought dialogue and collaboration with indigenous peoples and even began to see the museum as a service organization with responsibilities that include building and maintaining sustainable relationships with the people and cultures being showcased.

All of the essays described so far emphasize the need for collaboration between museum professionals and the people whose cultures and artifacts are displayed in museums. While scholars may have once obeyed a Star Trek-like "prime directive" of non-intervention in the lives and cultures of people under obser- 
vation, modern scholars have embraced interaction and collaboration with their subjects. Manuelina Maria Duarte Cândido, Andréa Dias Vial, Henrique Gonçalves Entratice, Rafael Santana Gonçalves de Andrade, and Nei Clara de Lima present a dramatic example of this in their essay on how researchers studying the ritxoko clay dolls of the Iny Karajá people developed a public health campaign during the COVID-19 pandemic. The researchers came to believe that the health and safety of the Iny Karajá were within the scope of the project because they were the sole practitioners of ritxoko. Thus, they provided masks and shared information about the disease with the people they were studying.

A similar evolution of attitudes happened among the administrators of the Centre Culturel Tjibaou in New Caledonia. As Quitterie Puel and Fabien Van Geert describe it, the Centre began as an institution to help preserve and display artifacts of the Kanak culture, but it has since become an example of the importance of "cultural institutions in the nation-building process," though there have been obstacles and resistance along the way.

Funding is a constant problem for researchers. While various government agencies provide many of the grants that keep institutions operating, recent decades have seen increases in philanthropy from corporations and private businesses. Patricia A. Banks proposes and analyzes the concept of "branding indigeneity," where companies benefit from their public, and well-advertised, relationships with indigenous cultures. There has been a long history of racial branding in the United States, which in past decades mostly targeted white audiences. Changing demographics, anti-discrimination laws, changing racial attitudes, immigration, and the expansion of the middle class to include more ethnicities, have prompted corporations to show that they respect and value diversity. While it may feel cynical to some, such corporate patronage has paid for the creation and maintenance of institutions such as the National Museum of the American Indian, which can count Coca-Cola, Chase Bank, Merrill-Lynch, and Northrop Grumman among its patrons.

\section{Conclusion}

The arguments and analyses presented here are going to be essential to the future study of museology. The relationship of the researcher to the subject has changed dramatically in recent decades, and will continue to change as the museum industry pursues greater inclusivity, equity, and diversity. Those pursuits will require greater collaboration between the institution and the community that it claims to study and represent. As the entries in this volume demonstrate, many museums and museologists have already embraced this development and will provide examples for other organizations going forward.

\section{Acknowledgements}

My thanks to all of the museum professionals who worked behind the scenes and who presented at the 2018 and 2020 symposia for all of their hard work, 
brilliant ideas, and friendship. Thanks also to the Liberal Arts department, the Center for Online Learning and Teaching, and the marketing department at Southern New Hampshire University for providing various resources. Thanks of course to the International Committee for Museology, the International Council of Museums, and the Association of African American Museums for their support. Thanks most of all to Susie Chung, who proposed the initial concept, identified and tracked down presenters, drafted the Call for Papers, the program schedule, and other documents, and generally held everything together while I was distracted by the ordinary and extraordinary bureaucratic crises that appeared during the COVID-19 pandemic. Susie gets stuff done.

\section{References}

Brulon Soares, B. (2020, August 27). Theoretical museology and community practice: A post-colonial approach. Keynote address. Theoretical Museology in U.S. and Tribal Contexts. Online symposium.

Davis, A., Denning, R., and Chung, Y.S.S. (2018, June 1). Working historians [Audio Podcast]. https://workinghistorians.podbean.com/e/ann-davismuseum-specialist-professor-and-icofom-board-member/.

Denning, R. (2019). From "cabinets of curiosities" to decolonization: A crash course in Museum Studies. In Y. S. S. Chung, A. Leshchenko, and B. Brulon Soares (Eds.), Defining the museum of the 21t century: Evolving multiculturalism in museums in the United States (pp. 29-34). International Committee for Museology. 